\title{
Effects of Financial Planning in UMWALIMU SACCO on Socio-Economic Development of Teachers in Rwanda: a case of UMWALIMU SACCO
}

\author{
Wilson Rurangwa ${ }^{1}$ and Ernest Safari ${ }^{2}$ \\ ${ }^{1,2}$ Business and Economics, Mount Kenya University \\ Kigali, Rwanda
}

\begin{abstract}
The overall intention of this study is to assess financial planning and socio-economic development of teachers in Rwanda. Descriptive research design was used whereby both qualitative and quantitative methods were applied. The population under this research involved all members of UMWALIMU SACCO in Kicukiro District branch in Rwanda that is made of 1,765 members as per 30th December 2018. Stratified sampling was used which is a probability sampling method such that the subpopulation within the general population have been incorporated in the sample selected in a balanced manner. This study to a significant extent depended on information about UMWALIMU SACCO Kicukiro Branch and their beneficiaries. Available handbooks, relevant information from the organizations' websites, journals made up the secondary data were used by the researcher. After the collection of data, the researcher edited and code the data. The statistics revealed that there was statistically significant relationship between teacher's contribution and the ability to start other income generating activities. Majority of the teachers joining UMWALIMU SACCO are motivated by access to loan which significantly contributes to increase in household income, improved access to medical services, access to children education and finally improves the ability to start other sources of income generating activities..

Keywords: Financial Planning, Socio-Economic Development of teachers, Rwanda and Credit Cooperatives, SACCOS, UMWALIMU SACCO
\end{abstract}

\section{Introduction}

The researcher intends to bring out the concept of financial planning in saving and credit cooperative societies and how does it affect the members of those savings and credit cooperatives. According to
Getachew (2016) the intention of developing Saccos was to assist the members to exercise saving by pooling together little amount they can get to facilitate borrowing among each other without taking risk and without handing too much power to money lending institutions. Relatively, in different African countries, SACCOs have been established in various sectors mainly targeting to improve the socioeconomic status of the low-income earners. There has been a success to some extent and a failure to another. This mainly depends on the day to day management of these SACCOs and relatively affects the achievement of their objectives.

The SACCO industry is part of the cooperative sector in Rwanda, which has impacted on lives of many Rwandans over the years. The development of such groups emerged rapidly due to lack of sufficient financial incentives. SACCOs exist in nearly all sectors of economy. UMWALIMU SACCO is one of the vibrant cooperatives which was formed in Rwanda to support teacher's welfare. The government of Rwanda implemented a combination of benefits and encouragement for the teachers to practice saving in order to supplement their low wages especially for primary and secondary schools' teachers (Muyombano and Mbabazize, 2016).

Teachers are being encouraged to form cooperatives at their schools to facilitate them access big loans for big income generating projects especially in transport, agriculture and business. This organization need to develop strong financial planning systems since it handles the huge finances of teachers from the entire country. Based on the above background, the researcher intends to assess the effect of financial planning of UMWALIMU SACCO and socioeconomic development of Teachers in Rwanda. 


\section{The life Cycle Theory of Savings}

The lifecycle theory of saving emphasizes that people when they are young they finance their consumption than savings for their retirement. The model provides that individuals can soften the consumption in the sense of maintaining marginal utility constant, through different stages of life. The model provides for loans prior to entering the labour market, the accumulation of wealth during work life and dissolution in retirement (Browning \& Crossley, 2001).

Karagu and Okibo (2014) highlighted that in a rapidly growing population, families have to support many children and would result to more consumption, and therefore saving will be low. Therefore, he concluded that in general, national saving rates are higher in a situation where dependency rates are lower and lead to rapid economic development. The theory also emphasized on the choice of people to save excess fund for future use and these funds can be deposited in financial institutions to help people with low income earning. It is in this context that SACCOs plays an important role in solving problems of the poor (Kiaritha, 2015).

Lifecycle theory may not be practicably applicable in our case because it advocates for people to make savings during their productive period particularly at a middle age level such that when one retires or becomes old, will start to consume the savings without depending on anyone. On the other hand, SACCOs operate in a different model of encouraging member to save in order to access loans.

Theory of micro-loan borrowing rates \& default

Microfinance loans model is used to determine the equilibrium debt rates and the probability of default. Monitoring this process is critical to ensure that there is balance in loan maturities without taking longer period. However, with short term loans, monitoring is counterproductive. Loans rates depend on market structure, monitoring cost, joint liability provision and technological advancement. The design of the loan contract for borrowers to make higher payments in good states and lower payments in bad states is shown as a parental improvement (Hitt, Bierman et al., 2006).

This theory is suitable for SACCOs because they operate in markets where the lender has no access to physical collateral and where the borrower is heavily capital constrained. This theory of micro loans incorporates; a) the absence of access to physical collateral, b) peer monitoring, c) threat of punishment upon default, and d) costly monitoring by lenders is used to determine the equilibrium borrowing rates.

\section{Data collection methods}

A descriptive survey design was employing Questionnaires and interviews were used to collect primary data. A descriptive research approach was carried out by use of participatory questionnaires with open ended as well as close questions.

This approach is carried out by use of participatory questionnaires with open ended as well as close questions. The targeted population of this research involved all members /accounts holders of UMWALIMU SACCO in Kicukiro District totalling to 1,765 . The sample size was 95 which was calculated using Slovin's formula with a margin error of $10 \%$ and confidence level of $90 \%$. During the data collection 95 questionnaires were distributed to the respondents as per the sample size but due to time and attitude of respondents only 91 questionnaires were filled and returned to the researcher.

\section{Results}

To obtain the required information, the research asked some of the questions and some of the questions asked include;

As a member of UMWALIMU SACCO, do you normally contribute any amount of your salary to the SACCO? The question was posed to the respondents and the obtained information are tabled below.

Table 1: members of UMWALIMU SACCO contribution of any amount of theirvsalary to the SACCO

\begin{tabular}{lcc}
\hline $\begin{array}{l}\text { Expended } \\
\text { response }\end{array}$ & Frequency & Percent \\
\hline Yes & 59 & 83.1 \\
No & 12 & 16.9 \\
Total & $\mathbf{7 1}$ & $\mathbf{1 0 0 . 0}$ \\
\hline
\end{tabular}

Source Primary Data 2020

According to the findings from the teachers' side, $83.1 \%$ of the respondents indicated that they make their normal contribution which according to the terms it's a personal obligation as well as government policy that made mandatory to the employers to make deductions from the net pay of the teachers. Twelve respondents which represented $16.9 \%$ of the respondents indicated that they were not making substantial contributions. The motivation by the fact that when one wants to acquire a loan from the Sacco based on their savings and this made teachers increasing their savings so that they can benefit more during borrowing.

National Policy on Cooperatives (2002) recognizes cooperatives as a distinct economic sector and 
integral part of the socioeconomic system of the country and an effective and potential instrument of socio-economic development.

Table 2: Whether respondents has acquired a loan from UMWALIMU SACCO

\begin{tabular}{lcc}
\hline $\begin{array}{l}\text { Expected } \\
\text { response }\end{array}$ & Frequency & Percent \\
\hline Yes & 58 & 81.7 \\
No & 13 & 18.3 \\
Total & $\mathbf{7 1}$ & $\mathbf{1 0 0 . 0}$ \\
\hline Primary Data 2020 & &
\end{tabular}

According to the findings, $81.7 \%$ of the respondents said they have acquired a loan from UMWALIMU SACCO while $18.5 \%$ of the respondents said that they haven't taken a loan from the Sacco. This implies that in general, majority of the teachers have been able to access loan from UMWALIMU SACCO ever since they started joining the Sacco. When asked the impact of UMWALIMU SACCO on socio-economy of teachers majority of them cited the following... 'the SACCO facilitated me to accumulate savings, build a good house, raise tuition fees for my children as well as my further studies, enable me to access good health, enrolled my children to a good school, start myself an income generating activity; my family welfare has improved...".

Their recommendation suggests that; ..."interest rates on emergency loans need to be reduced," cited a beneficiary. Another respondent cited..."UMWALIMU SACCO should introduce mobile banking services to enable easy access of financial services

Table 3: Relationship between financial planning and socio-economic welfare of teachers

\begin{tabular}{|c|c|c|c|c|c|}
\hline $\begin{array}{l}\text { Questions } \\
\text { posed during } \\
\text { the data } \\
\text { collection }\end{array}$ & $\begin{array}{l}\text { Statistical } \\
\text { Method used }\end{array}$ & $\begin{array}{l}\text { Improv } \\
\text { ement } \\
\text { in } \\
\text { househo } \\
\text { ld } \\
\text { income }\end{array}$ & $\begin{array}{l}\text { Incre } \\
\text { ase } \\
\text { access } \\
\text { to } \\
\text { medic } \\
\text { al } \\
\text { servic } \\
\text { es }\end{array}$ & $\begin{array}{l}\text { Increased } \\
\text { access to } \\
\text { children } \\
\text { education }\end{array}$ & $\begin{array}{l}\text { Abili } \\
\text { ty to } \\
\text { start } \\
\text { othe } \\
\text { r } \\
\text { sour } \\
\text { ce of } \\
\text { inco } \\
\text { me }\end{array}$ \\
\hline $\begin{array}{l}\text { As a member of } \\
\text { UMWALIMU }\end{array}$ & $\begin{array}{l}\text { Pearson } \\
\text { Correlation }\end{array}$ & .018 & .172 & .045 & $.543^{*}$ \\
\hline $\begin{array}{l}\text { SACCO, do you } \\
\text { normally }\end{array}$ & $\begin{array}{l}\text { Sig. } \\
\text { tailed })\end{array}$ & .882 & .152 & .711 & .000 \\
\hline $\begin{array}{l}\text { contribute any } \\
\text { amount of your } \\
\text { salary to the } \\
\text { Sacco? }\end{array}$ & $\mathbf{N}$ & 71 & 71 & 71 & 71 \\
\hline $\begin{array}{l}\text { What was your } \\
\text { motivation to join }\end{array}$ & $\begin{array}{l}\text { Pearson } \\
\text { Correlation }\end{array}$ & $.289^{*}$ & $.452^{* *}$ & $.401^{* *}$ & $.350^{*}$ \\
\hline $\begin{array}{l}\text { SACCO } \\
\text { cooperative? }\end{array}$ & $\begin{array}{l}\text { Sig. } \\
\text { tailed })\end{array}$ & .014 & .000 & .001 & .003 \\
\hline $\begin{array}{ll}\text { (Tick } & \text { all } \\
\text { appropriate) } & \end{array}$ & $\mathbf{N}$ & 71 & 71 & 71 & 71 \\
\hline
\end{tabular}

*. Correlation is significant at the 0.05 level (2tailed)(Source: Primary Data, 2019)
There is high positive correlation between members' contributions to the Sacco and their wellbeing, in order to assess the impact of these contributions on household income, access to medical services, access to children education and the ability to start other sources of income. The statistics revealed that there was significant relationship between teacher's contribution and the ability to start other income as indicated by Pearson correlation value of $0.543^{* *}$ which was significant at a p-value of 0.000 . Eventually, this improves their socio-economic status and therefore financial planning affects socioeconomic development of teachers.

According to Table 3 the members' contribution works as the basis of the loan to be acquired. This means that the loan acquired has a positive relationship with improvement in household income, increase access to medical services, increased access to children education, ability to start other source of income. This shows a positive relationship between financial planning and socio-economic development of Teachers in Rwanda.

\section{Conclusion}

The study revealed that UMWALIMU SACCO Management has to increase awareness of its members for the saving culture because withdrawals are higher than deposits this is due to the fact that salaries for members are immediately withdrawn leaving their accounts at zero balance. This affects the capacity to borrow since savings are part of key conditions for being given a loan. Also, UMWALIMU SACCO Management must revise the strategies and focus a lot on income generating activities.

Salary only will not completely address what teachers need unless other initiatives and innovations that can generate wealth are supported. In order teachers to be above poverty line there is a need to increase their income so as to reach at minimum standard of living and to be given the respect they deserve because they are role models in the community and agents of change in fighting ignorance, disease and to educate future generations. UMWALIMU SACCO is contributing to effective delivery of curriculum in schools, teacher retention, and motivation and is causing multiplier effects in the community through joint ventures and business interactions with the community. Government of Rwanda has been giving direct financial assistance as a start-up capital to provide initial operating costs and meeting infrastructure needs. Referring to the positive impact of UMWALIMU SACCO as mentioned by the respondents, and which are conservatively related to the income increase, and shows that UMWALIMU SACCO was established 
when it was highly needed by both the government to address the issue of low salary and teachers to address their socio- economic requirements.

As the study focused on the effect of financial planning and socio-economic development of teachers the research recommends the further studies on the effects of financial control and socioeconomic development of Teachers as well as the effects of working capital management and socioeconomic development of Teachers.

\section{Acknowledgement}

I wish to acknowledge Dr. Ernest Safari for her contribution to this work from the beginning up to it's the completion. I also wish to extend my acknowledgement to the Mount Kenya University, UMWALIMU SACCO authorities for their support and collaborative in terms of data collection.

\section{References}

[1] Browning, M., \& Crossley, T. F. (2001). The lifecycle model of consumption and saving. Journal of Economic Perspectives, 15(3), 3-22.

[2] Hitt, M. A., Bierman, L., Shimizu, K., \& Kochhar, R. (2006). Direct and moderating effects of human capital on strategy and performance in professional service firms: A resource-based perspective. Academy of Management journal, 44(1), 13-28.

[3] Karagu, J. M., \& Okibo, B. (2014). Financial factors influencing performance of Savings and Credit Co-operative Organization in Kenya.

[4] Karagu, J. M., \& Okibo, B. (2014). Financial factors influencing performance of Savings and Credit Co-operative Organization in Kenya.

[5] Kiaritha, H. W. (2015). Determinants of the financial performance of savings and credit cooperatives in the banking sector in Kenya (Doctoral dissertation).

[6] Muyombano, A., \& Mbabazi, M. (2016). Contribution of Umwalimu Savings and Credit Cooperative (UMWALIMU SACCO) On Socio Economic Development of Teachers in Rwanda. International Journal of Scientific and Research Publications, Volume 6, Issue 12. http://www.ijsrp.org/research-paper-1216/ijsrpp6027.pdf

[7] Nyambere, F.K (2013). Effect of credit risk management on financial performance of deposit taking saccos in Kenya. Research project, University of Nairobi.

[8] Omisore, I., Yusuf, M., \& Christopher, N. (2011)" The modern portfolio theory as an investment decision tool', Journal of Accounting and Taxation, 4(2), 19-28. 